\title{
Country Reunification in the Cold War: The Case of Korea and Vietnam
}

\author{
Chi Hieu Hoang ${ }^{1}$ \\ ${ }^{1}$ Associate Professor, Department of History, University of Education, Hue University, Vietnam
}

\begin{abstract}
The striking characteristics of the international relations in the second half of the twentieth century is that along with the division of the world into two confrontational systems, some countries were divided into opposing institutes such as the case of Germany, Korea and Vietnam. Despite the hindrances caused by the Cold War, Vietnam and Korea possessed similarities in their efforts to reunify the country. However, Vietnam was successful while Korea is still splited till present.
\end{abstract}

Keywords: Korea, Vietnam, reunification, separation

\section{Introduction}

During World War II (1939-1945), both Korea and Vietnam became colonies of the Empire of Japan. When the War nearly came to the end, the winners faced urgent requirement of deciding the fate of the losers and victims, dividing their benefits and established a new world order. Many international conferences had been organized to solve these problems, among which were Yalta Conference (February 1945) and Potsdam Conference (July 1945).

At Yalta, the United States, the United Kingdom and the Soviet Union decided to divide Korea into two occupied zones to laid down Japan's arm. Korea was occupied by the United States and the Soviet Union, with the boundary being the 38th parallel. After that, at Potsdam, the superpowers divided Indochina into two other occupied zones, taking 16th parallel as the boundary, the Northern part was put under the controlled of China, and the South by the UK. Therefore, the common point of the two countries was that their fates were put in the hands of the superpowers (firstly mentioned the US and the Soviet Union) without taking into consideration their aspiration. However, while the superpowers easily occupied North Korea and force them to follow their own orbit, Vietnam did not resign to the fate. Under the leadership of League for the Independence of Vietnam, the people had struggled to hold the power and played the role of the country's owner to welcome the allies. This was what (along with the return of the French colony under the support of the US and the UK) decided the next developments of Vietnam politics which was beyond the aspiration of the allies as well as what they had carried out in Korea.

Along with the launch of Cold War, the United States pushed the Soviet Union into a fierce arm race. Almost all of the countries in the world fell into the spiral of this confrontation, firstly mentioned the countries affected by these two superpowers, and the Korean was not an exception, though.

\section{Situation Of The Separation}

\subsection{The 38th parallel}

From just two occupied regions formed to disarm the Japan, 2 separate nations with opposing political institutes were established in the Korean peninsula: the Republic of Korea (South Korea) (May 10, 1948) which was put under the United States patronage and the Democratic People's Republic of Korea (North Korea) (September 09, 1948) under the administered of the Soviet Union (Appleman, 1992). The 38th parallel become the boundary divided Korean peninsula and also the boundary of the socialism and imperialism in Northeast Asia. There were only three possible crossing points along the line with limitation of travelling, that were the joint security area Panmumjom, the rail and the road connected the two countries. 


\subsection{The 17 th parallel}

While the cause of the separation of Korea was quite simple, that of Vietnam had undergone complex process. In Vietnam, Viet Minh had took control over the country before the Allies entered, as a result, these forces could not be able to set up their own governments as what was done in the Korea. They had to reach a compromise among themselves for the overall purpose of overthrowning the newly established revolutionary government. Therefore, when the UK army withdrew (February 1946) and the Chinese troops returned to their country (September 1946), there were only two opposing forces, one was the whole nation of Vietnam leading by Ho Chi Minh government and the other was the French colony and its collaborators. Due to the unique revolutionary characteristics, Vietnam did not develop opposing institutes like what superpowers created in Korea after World War II. However, from protecting the freedom that was newly established, the resistance war against French colony of Vietnam had gradually entered the Cold War when superpowers began to take intervention. When the correlation between forces in the battlefields could not bring the war to an end, the parties had to sit down to discuss at Geneva (1954). After 75 days of negotiation (May 08, 1954 to July 21, 1954), the superpowers participating in the conference, firstly mentioned France and China decided to take the Hien Luong river - the 17th parallel to be the temporary military line for two years. Associated with the separation of Vietnam was what was called "the responsibility of the world" in making sure that "the military line at the 17th parallel is just temporary" as mentioned in the Geneva conference. Implementing the Agreement, a temporary military line of about $20 \mathrm{~km}$ long and a demilitarized zone about $2.5 \mathrm{~km}$ to $6.0 \mathrm{~km}$ wide was established at Hien Luong river. Hien Luong bridge and 9 other wharves connected the river. From February 21, 1955, crossing the line was put under controlled. Those who wanted to travel to the North or the South must possessed a kind of travel permit issued by the Demiliterized Zone Board (including the temporary permit for citizen outside the Demiliterized Zone and the regular one for those living within the zone). In conclusion, the 17th parallel is an open control line where all of the people in the North and the South can pass freely (Hoang, 2017).

However, stemming from the strategic requirement of preventing the revolution wave spread to Southeast Asia and taking advantage of the failure of France, the United States accelerated its intervention to the South of Vietnam by setting up Ngo Dinh Diem government, supporting this government to reject the general election demanding for country reunification, and at the same time terrorized opposing and revolutionary forces. The establishment of Republic of Vietnam government (October 1955) transformed the South of Vietnam to a separate country. The 17 th parallel from the temporary demilitarized line "became one of the most restricted borders in the world", (Herring, 2004) the most fierce confrontation point between the national liberation movement and the modern colonialism, and between socialism and imperialism in Southeast Asia. The parallel was also "the place where the world's primary conflict concentrated, and the resistance war against the US to save the country of our people became the typical struggle, the focal point of the fierce fight between revolution and counter-revolution of the world; the liberation and protection war bearing typical characteristics of the time" (Vietnam Communist Party, 2003).

These are the factors that make the process of reunification of Vietnam differ from that of Korea.

\section{The Country Reunification Efforts}

\subsection{In Korea}

In order to prevent a long-term separation of Korea, in November 1947, the United Nations General Assembly proposed a general election which was intended to be put under the supervision of an international board to reunify the peninsula. However, the Soviet Union rejected this solution. (Appleman, 1992). Right after the establishment (September 09, 1948), the Democratic People's Republic of Korea decided to employed forces to regain the unification for the country. Under the auspices of the Soviet Union, on July 26, 1950, with the support of a powerful armed force, North Korea military crossed over the 38th parallel. The alliance of 17 countries leading by the US under the name of United Nations began to take intervention methods. Korean war 
broke into a conflict between the two opposite parties when more than 3 million of Chinese troops participated in the "War to Resist America and Aid Korea" and also the material reinforcement of the Soviet Union to North Korea. After 3 years (1950-1953) of fierce conflict which brought no winner, the war ended with the Panmunjom Agreement (July 27, 1953) without deciding any political solutions and as a result, the war between the two countries could not came to a stop.

When military solutions did not bring expected results, North Korea pursue the dream of reunifying the country based on the standpoint "one united Korea", and did not recognize the government of the South. Mean while, South Korea government also considered themselves as the only legal one in the Korean peninsula and the reunification meant the expansion of the country sovereign. The difference in the two countries point of view made it difficult to negotiate. By the 1970s, along with the détente trend of the two parties, the relationship between the two countries gradually improved. The two regions of Korea recognized each other's government, which also meant acknowledged the separation of the peninsula without finding the solution for unification. In 1991, the two countries were recognized when they were allowed to become members of the United Nations at the same time. As a result, the separation in the Korean peninsula continued. The remnants of the World War II and the confrontation of the two opposing sites in the Cold War still have not been solved. This is the "debt" that related superpowers owned Korea.

\subsection{In Vietnam}

The general election to reunify the country in July 1956 could not be implemented as France withdrew from the South of Vietnam and the US replaced, and especially because "the government of the South Vietnam (by the instigation of the US for this country feared that the communist force would dominate) refused to organized the consultative conference on July 1955. While the Democratic Republic of Vietnam respected Geneva Agreement, the South of Vietnam had to take responsibility for their own behaviors in front of the international community" (Bellessa, 2005). In order to regain freedom for country reunification, the government of the Democratic Republic of Vietnam had repeatedly sent statement and diplomatic notes requiring the government of Republic of Vietnam to conduct a general election (Statement on February 04, 1955, June 06, 1955, diplomatic note on July 19, 1955; May 11, 1956, July 18, 1957; March 07, 1958, December 22, 1958 ...). Not only did not approve, the Republic of Vietnam government even suppressed all struggles requesting for general election for country reunification of the North as well as implementing the cruel "national policy" to denounced communist, causing severe lost to the communist force. Even more seriously, Ngo Dinh Diem and his successors were haunted by the idea of "filling up Ben Hai river, heading towards the North". The Demilitarized Zone in the South and the vicinity was turned into a military land-air force base by the US and Sai Gon government to spread to the South. The Republic of Vietnam sent commandos, spies to the North to gather information and created "the war in the inner of communists" to weaken the North, hence they could not be able to support the revolution of the South and developed the land war to the South of 4th Military Region (Hoang, 2017).

Facing unfavorable condition for the implementation of the Agreement caused by the US and the Republic of Vietnam, the two presidents of the Geneva Conference - the UK and the Soviet Union only acted as the observers. When the UK refused the request of the Democratic Republic of Vietnam government (April 09, 1956) to convoke the Geneva Conference again to discuss about the implementation of the Agreement, the Soviet Union did not take appropriate measure to force the related parties to strictly followed. At that time, Southeast Asia in general and Indochina in particular were not on the top concerned of the Soviet Union. The Soviet Union just considered the South of Vietnam as a part of the national independence movement, so they afraid of the possibility that "a fire that can burn the entire forest". They would prefer Vietnam to implement the Geneva Agreement than carry out a fight in the South and at the same time, did not take strong reaction to the destructive actions of the US and Ngo Dinh Diem government. Even at the beginning of 1957, the Soviet Union proposed to accept both Democratic Republic of Vietnam and Republic of Vietnam into the United Nations, the reason that representatives of the Soviet Union gave out at the Conference was "there are two separate governments in Vietnam" (Vietnam Military History Institute, 1996). For China, in order to keep a peaceful, stable environment 
for development, the ideology of "co-exist in peace" hold a key position in the foreign policy of that country when Beijing asserted great influence on the Asia-Africa Summit in Bandung, Indonesia (April 1955), they began the negotiation with the US and unilaterally withdrew troops from Korea (1958). Therefore, the advice that leaders of China gave out to Vietnam was "longterm ambush", should not launch the struggles in the South impatiently.

Facing that situation, Vietnamese people had no choice rather than struggled for the country reunification in which the 17th parallel was the first boundary to overcome. The Resolution 15 was issued. Đồng khởi movement - partial movement of the people in the South broke out and developed into a revolutionary war, gradually defeated the US war strategies (special, local and Vietnamization war), reaching country reunification on April 30, 1975.

\section{Discussions}

\subsection{Common and different characteristics}

Bearing similar characteristics to Korea, the separation of Vietnam after Geneva Conference in 1954 was among the popular phenomenon of international relations after World War II. The common point was that two opposing institutes were developed in two countries (Korea and Vietnam): the North followed socialism and the South followed capitalism under the auspice of the US. Both countries were typical for the confrontation of the two world system in the Cold War (in Northeast Asia and Southeast Asia) where the main cause was the development of a new world order in the international relations which divided the world into two opposing social-political systems, leading by a superpower at each side.

However, while the separation of Korea started with the intention of the allied superpowers in dividing their fruits of the war against facism and deeply bear the stamp of the confrontation between socialism and imperialism, that of Vietnam rooted from a compromise among superpowers at Geneva Conference, and influenced by the national liberation war.

\subsection{Causes of success and failure}

Right after being separated by the Cold War and could not implement the general election, Korea attempted to reunified the country by means of force but did not achieve success due to both subjective and objective reasons. Objectively, the trend of that era did not allow them to organize the election. The confrontation between the East and the West was extremely tense, the US tried their best to maintain the 38th parallel, created a belt to prevent the expansion of the communist wave in Northeast Asia while the Soviet Union kept a dilly-dallying attitude to restrain, forced China to depend on them. As a result, the North Korea could hardly stop the war. (Weathersby \& Karathryn, 1993). Subjectively, the forces correlation did not allowed any party in the peninsular to take advantage, then could reunify the country. Due to the geographical conditions, the Democratic People Republic of Korea only way to advance to the South was crossing the 38th parallel, different from Vietnam which had the Truong Son trail. Generally speaking, the effort of Democratic People's Republic of Korea in crossing the 38th parallel in the complex situation of the 1950s was considered as the expansion of the communism rather than the reunification of the country, hence it did not receive the support of the people in the South as well as the international voice. When conversation tend to replace confrontation and the two countries of Korea were members of the United Nations, the possibilities of reunify the Korea country by employing force (of whatever country) was not feasible. After tense discussion of Trump and Kim Yong un in 2017, in 2018, there were breakthrough changes in the situation of the Korea peninsular. The peace statements between Kim Yong un and Moon Jae-in (April 27, 2018 and September 19, 2018) and the meeting of Trump-Kim Yong un (June 12, 2018) had opened up the possibility for a longterm peace and integration between the two Koreas. However, to reach the reunification for Korea, it still needs a long time, especially when the ideological opposition and the imprint of more than 7 decades of separation has created differences between the two sides of 
Korea even though they have made certain efforts such as establishing a team to participate in ASEAN Game 2018 or gradually eliminate the military control at the 38 th parallel...

In the case of Vietnam, from 1885, the long march for independence which attached to the country unification began with Can Vuong movement. Among various tendencies (feudalism, farmers, new intellectuals, bourgeois...), eventually by 1930, the country chose proletarian revolution. Therefore, proletarian revolution to Vietnam was firstly considered as a mean to liberate and unify the country. The starting point of the resistance war against French was the war to protect the independence that was achieved in the August 1945 revolution. After 5 years fighting, in 1950, when China, the Soviet Union and the socialist countries recognized the Democratic Republic of Vietnam and the US, UK and their allies recognized the Vietnam National government of Bao Dai, Vietnam gradually became the confronting focal point of the socialism and imperialism in Southeast Asia. After July 1954, the national liberation cause of the people of Vietnam had not been fulfilled. The struggle for an independent and unified Vietnam must be continued in different form and by appropriate methods. Similar to Korea, when the general election as mentioned in the Geneva Conference was rejected by the US and the Republic of Vietnam, finding another way for country reunification was inevitable. In the complex context of the world and the intentions of the allies, the Labour Party of Vietnam consistent with the objective of getting independence and autonomy, drew out the right revolutionary way, promoted the bravery and strong mind of the nation, took advantage of the power of that era to enhance the country position. Therefore, we could be able to obtain the support of modern world opinion (including the American), formed the firm international backers, and created the legitimacy for the leaders. The struggle for independence and reunification (1885-1975) of Vietnam for nearly a century deeply bear the characteristics of the national liberation movement in which the period of 1954-1975 was part of that long march.

Although being separated after Korea when "international responsibility" was not implemented, under the leadership of Vietnam Labor Party whose followed independent, autonomous resistance war; Vietnam people succeeded in eliminating the temporary military line at the 17th parallel, completed the national liberation cause, reunified the country before Korea.

\section{References}

[1] Laury-Anne Bellessa, "Vấn đề quyền lực và pháp lí trong việc thực hiện Hiệp định Genève tại Việt Nam: 1954-1956", Military History Review, vol. 7, pp. 14-19, July 2004.

[2] Chi Hieu Hoang, Demilitarized zone - The 17th parallel (1954-1967), publisher People's Army, Hanoi, 2017. ISBN 978-604-51-3147-3, pp. 37-53.

[3] George C. Herring, Cuộc chiến dài ngày của nước Mỹ và Việt Nam (1950-1975), (trans), Hanoi, People’s Police publisher, 2004, pp. 98.

[4] Roy E. Appleman, United States Army in the Korean War, South to the Naktong, North to the Yalu (June-November 1950), Washington, D.C: Center of Military History United States Army, 1992, pp.4.

[5] Vietnam Military History Institute, Lịch sử cuộc kháng chiến chống Mỹ, cứu nước (1954-1975), Tập 1: Nguyên nhân chiến tranh, Hanoi, National Politics Publisher, 1996, pp. 126.

[6] Vietnam Communist Party, Văn kiện Đảng Toàn tập, Tập 34 (1973), Hanoi, National Politics Publisher, 2003, pp. 35.

[7] Weathersby and Kathryn, Soviet Aims in Korea and the Origins of the Korean War, 1945-50: New Evidence From the Russian Archives, Washington, D.C: Cold War International History Project, 1993, pp. 34.

\section{Chi Hieu Hoang}

Place of birth: Quang Tri province, Vietnam; Date of birth: May 17, 1979. Mobile phone: +84914735779 . He defended his doctoral thesis in 2012, specialized in Modern and Contemporary Vietnamese History at the University of Education, Hue University, Vietnam. In 2018, he was awarded the title of Associate Professor by the State Council for Professor Title of Vietnam.

Currently, he is a history lecturer at the Department of History, University of Education, Hue University, Vietnam. He has been working in this position since 2007 and has obtained certain results. Some typical works can be listed such as the book: Đôi bờ giới tuyến, publisher General, Ho Chi Minh City, 2014; Demilitarized zone - The 17th parallel (1954-1967), publisher People's Army, Hanoi, 2017. 
19th CEBU - Philippines Int'I Conference on Economics, Education, Humanities \& Social Sciences (CEEHSS-19) Jan. 29-30, 2019 Cebu (Philippines)

ISBN 978-604-51-3147-3; Anti US Hi-tech War in Mc Namara Electronic Line (1966-1972), Hue University project, Code DHH201703-14, 2017-2018 and various papers in journals. 